\title{
WAAROM JAHWE WEIER DAT DAWID DIE TEMPEL BOU
}

\author{
J.L. Helberg \\ Departement Ou Testament \\ Potchefstroomse Universiteit vir Christelike Hoër Onderwys \\ POTCHEFSTROOM
}

\begin{abstract}
Abstrad
Jahweh's refusal of David's intended building of the temple (2 Sam. 7) does not reflect a nomadic ideal but rather stresses that Israel should not be concented with a human kingdom, one in which the idea of a human king (and prophet) has the highest authority. The inisiative lies in the Word and action of Jahweh; He is the real Sovercign, and the king is his senam. The human kingdom, with its human insight, planning and action is imperfect and crooked, even though it be that of the king (and prophet). The human kingdom thereforc needs a divine corrective (as in I Sam. 2:1-10; 8; I Sam. II fJ., 23, 24). The refusal funther stresses that Jahweh is not a (jod who is confincd to a building or the cult. The essence of true religion does not consist in fulfilling cultic duties but centres in personal communication with God in all aspects of life. Sening God is the fruit of divine election and covenant loyalty. Thue senice of God is brotght about by God's corrective Word by which He constantly calls for repentance and in fact also grnerates it.
\end{abstract}

\section{INI IEIIDING}

By die Kanaäniete in die tyd van ou Israel het die lokale heiligdomme en die heilige berge van die gode die land verteenwoordig wat die gode besit en regeer het en is as "erfenis" aangedui (vgl. Clements, 1965:54). Op soortgelyke wyse is dit in Israel so gesien dat die tempel van Jahwe 'n vergestalting daarvan was dat Jahwe die land besit en daaroor regeer (vgl. byvoorbeeld die Sionsliedere in Ps. 46,48,99).

Hier kan ook verwys word na 2 Samuel 6:2 waar Jahwe in sy verbintenis met die verbondsark genoem word: "Jahwe die Almagtige wat oor die gerubs troon". Dawid se voorneme om vir die ark, en dus vir Jahwe, 'n tempel te bou, lyk dus heeltemal natuurlik, aangesien Jahwe hom rus gegee het van sy vyande in die omgewing en die land dus toe stewig in sy besit was (2 Sam. 7:1-2). Keil (1950:344-345) sien hierdie tydperk selfs as die aanvang van die oprigting van die koninkryk van God. Hiermee word die tyd ingelui vir die bou van 'n blywende woonplek vir die Naam van Jahwe, dit wil sê vir die sigbare manifestasie van die teenwoordigheid van God onder sy volk.

God se weiering van Dawid se voorgenome tempelbou skep dus 'n probleem. Die rede 
wat in 2 Samuel 7 gegee word, is self oënskynlik problematies omdat dit net so goed vir Salomo geld as vir Dawid, en tog word gesê dat Salomo wel die tempel sal bou. Die aangegewe rede is dat God in tent en tabernakel rondgeswerf het saam met al die Israeliete en nooit een van die stamme beveel het om 'n huis wat met sederhout versier is, vir Hom te bou nie. Wat sou die eintlike rede vir die weiering wees? Hierdie gebeurtenis is van die grootste belang vir die hele geskiedenis van Dawid. Hertzberg (1968:233) sê dat 2 Samuel 7 die hoogtepunt van die hele oorlewering oor Dawid vorm. Tegelykertyd lei dit die berig in oor die troonopvolging wat baie sonde en verkeerdhede bevat. Deurdat vooraf verwys word na die durende dinastie word gesê: God het desondanks die voorneme om Dawid se huis te bou. Kalsbeek (1974:34-35) stel met 'n struktuuranalise vas dat die Natansprofesie van 2 Samuel 7:1-17 die middelpunt van die Samuelboeke as geheel en die sentrale boodskap daarvan vorm.

Hierdie artikel wil ingaan op die rede waarom Jahwe weier dat Dawid vir Hom die tempel bou.

\section{MOONTLIKE REDES VIR DIE WEIERING}

Die historiese basis van die Godspraak in 2 Samuel 7 word deur die meeste geleerdes erken (vgl. byvoorbeeld Rost, 1965:166; Clements 1965:56). Daar is redelike eenstemmigheid daaroor dat die volgende verse tot die oorspronklike vorm behoort: 1 7,11b,16,18-21,25-29 (Clements, 1965:56). Goslinga (1962:132-134) gee 'n bespreking van die verskillende benaderings asook oor die eenheid van die gedeelte as geheel.

Sommige geleerdes benadruk die bestaan van verskillende oorspronklike bronne wat in aanvulling tot mekaar of in teenstelling tot mekaar staan. Caird (1953:1082) sien byvoorbeeld vers $8 b, 9 a, 10 a b(a), 12,14-16$ as deel van 'n lied van 'n relatief vroeër datum. Daarteenoor dateer Caird die hoofprosageskrif later en meen dat dit beskou moet word as 'n aanval op die tempel. In hierdie geskrif word gebruik gemaak van 'n vroeëre profesie dat Dawid se huis ewig sal bestaan.

Ander geleerdes, soos Childs (1979:271-280) bekyk die saak meer vanuit die eenheid van die boeke Samuel waarin hierdie gedeelte voorkom. Ek sluit my hierby aan. Die lofsang van Hanna (1 Sam. 2:1-10) en die sogenaamde aanhangsel (2 Sam. 21-24) wat onder meer die laaste woorde van Dawid bevat, is volgens Childs nie misplaaste gedeeltes nie. Hulle moet uit 'n teosentriese perspektief verstaan word, en die fokus val op God se weg met sy gesalfde Dawid en staan tegelykertyd in die teken van Messiaanse hoop (1979:273,275). 2 Samuel 7 bevestig die Messiaanse verwagtings wat aan Dawid gekoppel is; dit geld ondanks Dawid se sonde en mislukkings (1979:276). Ackroyd (1981:386,388,390,396) waarsku teen 'n kunsmatige en hipotetiese kategori- 
sering van die teks en hy beskou die voorstelling van 'n identifiseerbare "troonopvolgingsgeskiedenis" as 'n voorbeeld hiervan. Hy pleit tereg vir 'n soepeler benadering waarin die verskeidenheid en rykdom van die teks tot sy reg kan kom.

In 1 Konings 5:3 (Hebreeus: 5:17) sê Salomo aan koning Hiram van Tirus dat Dawid nie die tempel kan bou nie omdat hy so dikwels in oorlog betrokke was (letterlik omdat hulle hom met oorlog omring het). Hierdie mededeling gee nie 'n antwoord op die probleem wat uit 2 Samuel 7 voortspruit nie. Dit gee slegs 'n antwoord op die vraag waarom Dawid tot op 'n sekere stadium nie in staat was om die tempel te bou nie, maar nie op die vraag waarom Jahwe geweier het toe Dawid wel in staat was om dit te doen nie. Volgens Salomo is hyself in staat om dit te doen omdat Jahwe hom rus gegee het (héniall) aan alle kante. In 2 Samuel 7:1 word dieselfde aangaande Dawid gesê. (Die vraag of 1 Konings 5:17 saam met die Qere gelees moet word dat Jahwe die vyande aan Salomo onderwerp het ("onder my voete"), of saam met die Ketib ("onder sy voet"), maak nie wesenlik verskil aan ons probleem nie en hoef nie hier verder bespreek te word nie, aangesien 2 Samuel duidelik is oor die "rus" wat rondom aan Dawid gegee is.)

Daar bestaan baie verskillende menings oor die rede vir die verwerping van die tempelbou. Clements (1965:57-58) wys op drie moontlike redes:

* Israel se "nomadiese ideaal" het gelei tot 'n afwysing van 'n permanente heiligdom vir 'n ark.

* Eerbied vir die ou amfiktionie met sy tentheiligdom het gelei tot 'n weerstand teen 'n gebou wat wesenlik Kanaänities in oorsprong en ideologie was.

- Politieke spanninge het teenstand geskep teen Dawid se beheer oor die stadskultus.

Hierteenoor stel Clements (1965:58) die volgende:

- Die sogenaamde "nomadiese ideaal" is grootliks oordryf; nomadisme was nooit Israel se norm vir ortodoksie nie.

* Die vashou aan die Israelitiese amfiktionie het nie uitgesluit dat daar vir die ark 'n tempel in Silo was nie.

- Ons weet min van die motiewe vir politieke verdeling in Dawid se tyd, maar behalwe persoonlike twiste in Dawid se familie was die belangrikste stryd blykbaar tussen elemente van Juda-Jerusalem en die ouer Israelitiese tradisies van Efraim in die noorde. Die oorsaak lê vir Clements in 'n kombinasie van politieke en religieuse faktore.

Volgens Rost (1965:234), gevolg deur baie ander, is die sogenaamde troonopvolgings- 
geskiedenis, en dus ook 2 Samuel 7, geskryf om Salomo se opvolging van Dawid te besing (vir variasies op die tema, vgl. Van Rooy, 1986:321-322; vgl. verder Kaiser, 1988:5-8).

Volgens andere het hierdie geskrif 'n anti-Dawidiese of anti-Salomoniese inslag (vgl. Van Rooy, 1986:322 oor die verskillende voorstanders hiervan). Van Rooy (1986:334) vergelyk die voorkoms van kerntemas in 2 Samuel 7 en dié in die res van die troonopvolgingsgeskiedenis. Hy sluit hom op grond daarvan aan by die beskouing dat ons met 'n dokument van breëre opset te doen het, naamlik 'n hofgeskiedenis. 2 Samuel 7 is nie die fondament van die troonopvolgingsgeskiedenis nie; daar is egter ook nie konflik tussen die twee nie, en die troonopvolgingsgeskiedenis is nie anti-Dawidies nie. Dit gaan oor hoe Dawid op die troon gebly het teen die agtergrond van God se inisiatief en Dawid se geloofsvertroue.

Van Seters (1983:273-274) wys tereg daarop dat 2 Samuel 7 nie negatief ten opsigte van die tempel vertolk moet word nie. Onder tydelike heersers, soos die rigters (v.11), was die woonplek van Jahwe beweeglik; eers wanneer 'n monargie gevestig (v.8) en Israel se vyande onderwerp sou wees (v.9), sodat Israel in sy eie plek kon woon (v.10), sou Jahwe 'n dinastie, 'n "huis", oprig en die eerste lid van hierdie dinastie vir I Iom 'n "huis" laat bou.

Anders as die algemene opvatting tot en met sy publikasie, sien Van Seters (1983:280, 289,290 ) die hofgeskiedenis as 'n na-Deuteronomistiese byvoeging tot die geskiedenis van Dawid in 'n na-ballingskapse tyd. In hierdie tyd het die tema van die Goddelike belofte aan Dawid in 2 Samuel 7 geneig om te ontwikkel in 'n "ewige verbond" met sterk Messiaanse ondertone. Die hofgeskiedenis is dus die vrug van 'n anti-Messiaanse tendens in sommige Joodse kringe van daardie tyd.

Kaiser $(1988: 6,7,15,20)$ wys hierdie opvatting van Van Seters af. Hy voer bewyse aan dat 1 Konings 2:5-9 (Dawid se opdrag aan Salomo oor Joab) 'n sekondêre bestanddeel van die vertelling oor koning Dawid is en konkludeer dat dit nie moontlik is om met 'n beroep op hierdie testament die troonopvolgingsgeskiedenis as 'n na-Deuteronomistiese voorstelling te benader nie. Kaiser wys op die spanninge in die vertelling self en skryf dit daaraan toe dat die verteller 'n goeie en spannende geskiedenis wou vertel. Die lewe self is so gekompliseerd soos die raaiselagtige vertelling oor koning Dawid. Die oplossing lè dus nie in die vraag of die vertelling pro-monargies of anti-monargies bedoel is nie.

Botha (1986:63-75) vergelyk buite-Bybelse parallele met 2 Samuel 7 en wys op ooreenkomste maar ook op belangrike verskille. Volgens hom bevat dié gedeelte 'n polemiese instelling teenoor die opvatting oor koningskap by Israel se Umwelt. Magte wat 
by die ander nasies aan die koning toegeken is, word in Israel as die voorreg van Jahwe beskou. In Israel noem die koning homself nie die geseënde van God nie, maar vra dat sy huis deur Jahwe geseën word. Die koning is nie die vader van sy volk nie, maar Jahwe sal Homself as die Vader van Dawid se nageslag bevestig. Dit is Jahwe wat teenoor die vyand optree en wat heerskappy uitoefen. Dawid sal nie sy eie dinastie vestig nie, maar Jahwe sal dit vir hom doen. Dawid word 'n groot naam belowe, maar dit dien slegs om die grootheid van Israel te benadruk en die Naam van Jahwe te eer. Die uitstel van die tempelbou dien dus blykbaar om die aanvaarde ou Oosterse idee oor die belangrikheid van die koning te verswak. Nie Dawid of sy nageslag nie, maar Jahwe is die eintlike koning; Hy bepaal die gang van die geskiedenis en besluit oor wanneer en waar' $n$ tempel gebou word, en dit is Hy wat toesien dat sy Goddelike plan nie gefnuik word nie.

2 Samuel 7 benadruk inderdaad die inisiatief en heerskappy van Jahwe, en wel met optrede sowel as met die woord. Jahwe praat oor wat Hy vir Dawid en vir Israel gedoen het, en Hy vra of Hy ooit vir een van die stamme "gese" het (v.7): "Waarom bou julle nie vir my 'n huis ... nie?" Hierdie inisiatief in daad en woord gaan hand aan hand met 'n korrektiewe optrede, 'n optrede wat 'n korrektief bied op die mens se optrede en wat oproep tot verandering in handeling en instelling. Dit raak veral die koning, maar ook die profeet. Selfs die koning, en die profeet, se mening is nie die norm vir die volk nie mar vereis inteendeel regstelling aan die hand van die enigste maatstaf: Jahwe se wil, soos geopenbaar in sy woord en optrede.

Behalwe dat die korrektiewe optrede van God met die Goddelike inisiatief en heerskappy saamhang, hang dit ook saam met ander aspekte wat agtereenvolgens behandel sal word: die persoonlike aard van Jahwe se heerskappy en optrede, Jahwe se verbondstrou en verkiesende optrede gepaard met die eis om bekering, die verhouding tussen die enigste en onvergelyklike God en sy dienaar.

\section{GODDEI IKE KORREKTIEF}

2 Samuel 7 bevat nie bloot God se weiering van Dawid se voorgenome tempelbou nie maar begin met 'n korrektief op die beplanning van Dawid wat deur die profeet Natan goedgekeur is; dus 'n korrektief op die koning sowel as die profeet.

Verder is daar in die hoofstuk ook sprake van 'n Goddelike korrektief op Dawid se seun, en wel dic seun aan wie besondere toekomsverwagtings verbind is. Die veronderstelling word uitgespreek dat daar ontrou by hom sal voorkom en dat Jahwe hom sal straf en kasty soos 'n vader met 'n kind doen (v.14-15). Ons lees van Jahwe se korrektiewe optrede in die res van die boeke 1 en 2 Samuel asook in die res van die Ou 
Testament, soos in die volgende bespreking aangetoon sal word.

In 2 Samuel 6 word gehandel oor Jahwe se korrektief op die oorbring van die verbondsark na Jerusalem toe (v.6-7). Die grootste gedeelte van 2 Samuel 9 en dit wat daarop volg, handel oor Dawid se owerspel met Batseba en die bitter gevolge wat daaruit voortgevloei het (hoofstuk 11 e.v.). Tog is Dawid nie deur God verwerp of aan homself oorgelaat nie. Hierdie geskiedenis is dus nie bloot veroordelend nie maar funksioneer as 'n korrektief. Volgens Samuel 21-24 en 1 Koning 1-2 eindig Dawid se geskiedenis daarmee dat hy met God versoen is; Batseba se seun is selfs sy opvolger en dus die een aan wie die besondere verwagtings van 2 Samuel 7 verbind is.

Volgens 2 Samuel 24 is Jahwe se optrede teenoor sy volk ook 'n korrektief deurdat Hy Dawid teen hulle aanhits om die volk te tel, waarop daar pes as straf teen die volk uitbreek, maar waarop daar uiteindelik tog weer redding volg.

Ook die boeke 1 en 2 Konings bevat 'n baie sterk korrektief op die koning en die profeet. In Konings is die korrektief egter nog veel skerper as in 2 Samuel 7 en lè dit veel meer op die vlak van veroordeling. Die korrektief word voorop in die geskiedenis van die konings van Israel gestel, byvoorbeeld by die optrede van die profeet wat vir koning Jerobeam die oordeel moes aansê oor sy offerandes op die altaar van die heiligdom wat hy in Bet-El laat oprig het. Die profeet vertoef te goeder trou by ' $n$ ou profeet wat voorgee dat God hom daartoe opdrag gegee het, maar moet met sy lewe daarvoor boet (1 Kon. 13). Hierdie geskiedenis wys dat 'n profeet in sy profetiese optrede slegs moet verkondig wat God aan hom sê; verder beklemtoon dit dat die profeet gedurig gevaar loop om 'n pad op te gaan wat nie in ooreenstemming met God se wil is nie en daarom behoefte het aan Goddelike kontrole en korrektief.

Ook in 1 Samuel 8 kom 'n Goddelik korrektief op 'n profeet voor, en wel op Samuel. Anders as in die geval van die profeet wat teen Jerobeam geprofeteer het, was dit by Samuel nie 'n veroordeling van ontroue optrede nie. Dit gaan daaroor dat Samuel die volk se versoek weier om vir hulle 'n koning aan te stel. Ook God keur die volk se versoek af, maar beveel tog vir Samuel om 'n koning aan te stel.

1 Samuel 8 is dus nie bloot 'n anti-monargiese bron nie, maar dit is in ooreenstemming met die aard van die profetiese opdrag in die algemeen. Dit is in dié opsig korrektief van aard dat 'n profeet nie volgens sy eie wil en denke moet optree nie, maar volgens Goddelike opdrag - iets wat dikwels anders is as wat die menslike wil of logika dit wil hè.

Ook die lofsang van Hanna (1 Sam. 2:1-10) is korrektief van aard. Dit handel oor God se korrektiewe optrede deurdat $\mathrm{Hy}$ die rolle in die samelewing omkeer: Hy verneder 
hoogmoediges en verhoog nederiges, Hy bewaar die voetstappe van sy troue dienaars maar laat die goddeloses vernietig word, Hy gee krag aan sy koning, sy gesalfde (v.710). Dit alles word betrek op die heerskappy van God in die gang van die koningskap en koningslyn van Dawid (vgl. ook Childs, 1979:273).

By die profete in die profetiese boeke is die Goddelike korrektief 'n bekende verskynsel, ook die korrektief op die profeet, soos hier op Natan (2 Sam. 7). Die profeet voel heel dikwels 'n spanning aan tussen wat hy self wil doen of verkondig en wat God hom beveel om te doen (Am. 3:8; Jer. 20). Die profete se beswaar teen valse profete is juis dat laasgenoemdes dinge verkondig wat uit hulle eie hart kom en nie 'n openbaring van God is nie (vgl. byvoorbeeld Jer. 23:16-32; 27:14-16; 29:8-9).

Samevatting: Uit die voorafgaande blyk dat die korrektiewe optrede van God teenoor Dawid en Natan nie geïsoleerd staan nie. Daar kan verbande gelê word met die oorbring van die verbondsark na Jerusalem toe (2 Sam. 6), met Dawid se geskiedenis soos beskrywe is in 2 Samuel 11 en volgende, en met dié van sy seun aan wie die besondere beloftes verbind word. Verder kan verbande gelê word met die profetiese optrede van Samuel by die instelling van die koningskap (1 Sam. 8) en met God se optrede in die geskiedenis van sy gesalfde koning en sy volk, soos beskryf in die loflied van Hanna (1 Sam. 2:1-10).

God se optrede in 2 Samuel 7 is ook in ooreenstemming met sy korrektiewe optrede in die verkondiging van die profete.

Hierdie korrektiewe optrede van God hang onder andere saam met die volgende:

\section{DIE GODDELIKE INISIATIEF EN HEERSKAPPY}

Die heel eerste vers van hierdie hoofstuk ( 2 Sam. 7) benadruk Jahwe se inisiatief en heerskappy: Dawid het in sy eie huis gewoon nadat Jahwe hom rus gegee het van al sy vyande in die omgewing. Van vers 5 af benadruk Jahwe, by monde van die profeet, teenoor Dawid dat dit nie hy is wat iets vir Jahwe moet doen nie maar dat dit Jahwe is wat vir hom (Dawid) iets doen. Jahwe het dit lankal reeds gedoen, toe Dawid nog agter die skape was, en ook daarna, toe Jahwe hom koning gemaak en sy vyande voor hom uit verdelg het. Nie Dawid sal vir Jahwe 'n huis bou nie, maar Jahwe sal vir Dawid'n huis bou (v.11).

Jahwe neem die inisiatief in alle gebeurtenisse, ja, in die geskiedenis as geheel. Daarom maak lly ook die toekoms vir Dawid oop en skenk hom wonderlike toekomsbeloftes wat in en deur sy eie nageslag bewerk sal word: 'n koningskap wat vir altyd 
vas bly staan $(v .13,16)$. Die Hebreeuse begrip 'ôläm beteken gewoonlik 'n lang tyd, of 'n onbepaalde tyd en het nic die filosofiese betekenis "ewigheid" nie (vgl. Jenni, 1976: 228 e.v.; vgl. ook Koehler-Baumgartner, 1953:688). Die nadruk wat hier op die begrip ôlän gelè word (vgl. verder v. 24,25,26,29), wys dat dit om meer as 'n baie lang tyd gaan, veral anngesien dieselfde term in dieselfde asem gebruik word in verband met die Naam van Jahwe (v.25). Hier word perspektiewe geopen wat ver bokant Israel se geskiedenis uitstyg (vgl. ook Hertzberg, 1968: 236).

Ook die voorafgaande hoofstuk benadruk die feit dat Jahwe die inisiatief behou: die verbondsark kan nie maar volgens Dawid en die volk se goeddunke vervoer en hanteer word nie. Dan straf Jahwe hulle soos vir Ussa wat die ark probeer vashou het toe die osse gestruikel het (2 Sam. 6:6-7).

Jahwe neem die inisiatief ten opsigte van gebeurtenisse asook in verband met sy Woord, soos reeds in punt 3 aangedui is. Hy bly in volle beheer daarvan en beskik vrymagtig daaroor. Dit geld ook die wyse van die godsdiensbeoefening. Hy het nie 'n voorskrif gegee oor sodanige godsdiensbeoefening nie. As Hy dit wou gehad het, sou Hy die woord daarvoor gespreek het: "Het Ek ooit vir een van die stamme wat Ek beveel het om die leiding van my volk op hom te neem, gesê: 'Waarom bou julle nie vir My'n huis wat met sederhout versier is nie?"' (7.7). Dit is die Woord van Jahwe wat dinge laat gebeur; daarom hid Dawid dan ook dat die Woord met sy belofte "in vervulling" moet gaan (v.25). Hierdie betekenis van die Woord geld ook en veral vir die plek en dus ook die aard van die godsdiensbeoefening, naamlik die tempel wat Dawid van voorneme was om te bou.

Jahwe beklemtoon dus dat sy Woord, en nie dié van die koning nie, die beheersende plek in die erediens inneem. Daarmee word die mag van die koning oor die religie, soos dit by die ander nasies in die heilige koningskap gestalte gekry het, by die wortel afgesny (vgl. ook Clements, 1965:59-60).

Die heerskappy van Jahwe word benadruk deurdat die woord aan Dawid ingelui word met: "So sế Jahwe Sebaôt", (v.8). Dié naam dui veral die almag van Jahwe aan (vgl. byvoorbeeld Van der Woude, 1976:505). Ook in Dawid se gebed gebruik hy hierdie naam wanneer hy vra dat Jahwe sy beloftes in vervulling moet laat gaan (v.26-27).

Jahwe se inisiatief en vrymag in verband met sy Woord word ook aan die begin van die Samuelboeke benadruk. Daar word meegedeel dat die Woord van Jahwe in daardie tyd min gehoor is; daar was nie dikwels openbarings nie. Jahwe bewys dan sy inisiatief en vrymag daarin dat Hy 'n nuwe begin maak deurdat Hy'n kind, Samuel, gebruik om 'n openbaring oor Eli en sy huis te gee (1 Sam. 3). Ook hier word gesea dat Jahwe sy woorde in vervulling laat gaan het (1 Sam. 3:19). Ook daarna het Jahwe Hom deur sy 
Woord aan Samuel geopenbaar (1 Sam. 3:21).

Samevatting: Die voorafgaande wys dat Jahwe se korrektiewe optrede saamhang met die feit dat Hy die vrymagtige Regeerder is wat in Dawid se lewe die volle inisiatief neem. Dit geld vandat Dawid 'n skaapherder was en ook nou dat hy as koning regeer. Jahwe regeer deur sy Woord in vervulling te laat gaan. Ook die godsdiensbeoefening en dus die tempel, word deur sy Woord bepaal. Daarom behou Jahwe ook en veral daarin die inisiatief en laat Hy dit selfs nie aan 'n profeet se inisiatief oor nie. God se wil is trouens anders as die mens s'n en werk korrigerend daarop in, selfs op dié van 'n profeet. Die mens moet God dus eers raadpleeg, en wel omdat Hy die Heerser is en ook omdat die mens ontspoor as hy dit nie doen nie. Hierdie feit sal nog duideliker in die volgende onderafdeling na vore kom.

\section{JAHWE IS 'N PERSOONLIKE GOD EN STAAN IN 'N PERSOONLIKE VERHOUDING MET DIE MENS}

In Jahwe se weiering van die voorgenome tempelbou word sterk klem daarop gelê dat God 'n persoonlike God is wat in 'n persoonlike verhouding met Dawid, sy seun en sy volk staan: Dawid het sy voorspoed as regeerder daaraan te danke gehad dat Jahwe by hom was (7:9; vgl. ook 5:10; en verder 8:6,14; vgl. ook March, 1981:397).

Die mededeling van Jahwe word daardeur beheers dat nie Dawid vir Jahwe 'n huis sal bou nie, maar dat Jahwe vir Dawid 'n huis sal bou. Die huis wat Jahwe vir Dawid sal bou, is van' $n$ heel ander aard as die een wat Dawid vir Jahwe wil bou. Die huis wat Dawid wil bou, is 'n tempel, 'n gebou; die gebou wat Jahwe sal bou, is 'n koningshuis, 'n nageslag (v. 11, vgl. ook 25-27,29). Jahwe sal vir Dawid se seun 'n vader wees; daar sal ' $n$ vader-kindverhouding tussen hulle bestaan (v. 14). Hier word nie aan ' $n$ generatiewe verhouding gedink nie maar aan ' $n$ vertrouensverhouding en erkenning van volstrekte afhanklikheid aan Jahwe (vgl. byvoorbeeld Vriezen, 1966: 188). Hier word seker die amptelike seunskap van die koning in sy verhouding tot God bedoel (Ps. 2:7; Botha, 1986:63), maar nie net uitsluitlik dit nie. Die klem val hier op die intieme verhouding, soos ook blyk uit die naam Jedidja (Jahwe het hom lief) wat Dawid aan Salomo by sy geboorte gee (2 Sam. 12:24-25; vgl. Goslinga, 1962:143).

Die seun sal in hierdie besondere verhouding met Jahwe wees kragtens hierdie belofte wat Jahwe aan Dawid gemaak het. Jahwe se verhouding tot hom sal dus uitgedruk kan word op soortgelyke manier as in die uitdrukking "Ek is die God van Abraham/Isak/Jakob" (Gen. 28:13; Eks. 3:16; 1 Kron. 29:18). Anders as die gode van die Kanaäniete en andere word Jahwe nie geken aan sy verhouding met plekke nie, maar aan sy verhouding met mense (vgl. Clements, 1965:15). Jahwe is 'n persoonlike God, en dit 
gaan vir Hom om 'n persoonlike verhouding met mense. Hy wil in die eerste plek onder en in mense woon eerder as in geboue, soos tempels; Hy wil in 'n vader-kindverhouding met mense leef, in die gewone lewe met al sy fasette, eerder as in 'n plek waar Hy met gawes soos offerandes gedien word. Jahwe wil by Dawid en sy seun wees soos Hy destyds by Dawid by die skape was en toe hy as koning voorspoedig opgetree het ( 2 Sam. 7:8-9).

Jahwe stel nie net die huis wat Dawid vir Hom wil bou teenoor die huis wat Hy vir Dawid sal bou nie, maar ook die plek wat Dawid vir Jahwe gereed wil maak, teenoor die plek wat Hy vir Dawid en sy volk gereed gemaak het: "Ek het 'n woonplek aan my volk Israel gegee en hom gevestig, sodat hy sonder vrees in sy plek kan woon" (v.10). Dit is Jahwe wat aan mense 'n woonplek gee en daarmee rus en beskerming bied; Hy self het nie 'n woonplek nodig nie. Die plek is ook nie 'n kultusplek, soos maqôm dikwels beteken nie (vgl. Gamberoni, 1984: 119-120), maar 'n woonplek.

Ook wat die mense, sy volk betref, is die plek op sigself nie belangrik nie. Hier is geen direkte verwysing na Jerusalem in hierdie hoofstuk nie. Die blik is wyer en is op die land gerig, en dan word die land ook nie met 'n eienaam of 'n ekwivalente naam aangedui nie, maar in algemene terme. Dit word aangedui as woonplek (maqôm, v.10) en as "hierdie land" waarin Jahwe nasies en gode uitgeroei het om sy volk daar te vestig (v.23). Die fokus is daarop dat daar 'n ruimte geskep is waarin die volk Israel Jahwe kon dien met hulle hele bestaan en in persoonlike toegeneentheid.

Maag (1959:129-153) laat nie genoeg ruimte vir wat in vers 10 en vers 23 uitgedruk is nie en beweer ten onregte dat Jahwe vir Israel 'n nomadiese God was. Sy standpunt is tereg deur Zimmerli (1971:57; vgl. ook Davies, 1974:86) verwerp. De Vaux (1968:14) wys daarop dat nomadisme self nie die ideaal was nie maar die suiwerheid van die godsdienstige lewe en getrouheid aan die verbond. Hierdie suiwerheid van die godsdienstige lewe en die getrouheid aan dic verbond was in Israel se gemoed geassosieer met sy vroeëre lewe in die woestyn.

Die sekondêre plek van tempel, stad en land in hierdie hoofstuk is in ooreenstemming met die algemene benadering van die Ou Testament. Vriezen (1962:4 e.v.) het tereg daarop gewys dat Jahwe nooit die "God van Jerusalem" genoem word nie, behalwe in 2 Kronieke 32:19 waar dit in werklikheid 'n heiden in die mond gelê word. Verder kan ons daarop wys dat Jahwe ook nie die God van 'n plek genoem word nie. Die aanduiding "God van Bet-El" in Genesis 31:13 is alleen moontlik as die lidwoord by "God" geskrap word. Nêrens elders word 'n woord vir "God" in 'n genetiewe verbinding met 'n pleknaam gebruik nie: die Skrif bind God nie aan 'n plek nie. 'n Beter lesing volgens die LXX en die targoems sou wees: "die God wat aan jou verskyn het te Bet-El", 35:7 (Van Selms, 1967:116; vir ander moontlikhede vergelyk Gamberoni, 
1984: 1119; De Vaux, 1968: 291-292).

Uit die voorafgaande blyk dit dat daar in hierdie hoofstuk nie plek is vir 'n moontlike mitologiese siening wat aansluit by die vroeëre, Jebusitiese inwoners se siening en waarvolgens Jerusalem 'n plek met bonatuurlike betekenis is nie. Dit gaan om God se persoonlike teenwoordigheid en sy historiese optrede waardeur Hy sy volk en vir Dawid tot op hierdie punt gebring het. Van belang hier is dit wat Clements (1965: 48) in 'n enigsins ander verband stel. Hy sê dit is veelbetekenend dat Jahwe se woon in Jerusalem uitgedruk is in terme van sy "verkiesing" van Sionsberg (Ps. 78:68, 132:13) geskiedenis, eerder as mite, is gesien as regverdiging vir sy verblyf daar.

Behalwe dat Jahwe nie die God van 'n stad of 'n plek genoem word nie, word Hy ook nie die God van die (beloofde) land genoem nie. Dit staan in sterk teenstelling met die geval by die ander nasies, soos die Assiriërs, wat wel na Jahwe, soos na hulle eie gode, verwys as "die God van die land" (2 Kon. 17:26). Die Ou Testament noem God wel die God van persone: "die God van jou vader", of "die God van Abraham, Isak en Jakob" (Gen. 28:13; Eks. 3:16; 1 Kron. 29:18), en "die God van Israel", soos hier in 2 Samuel 7:25-26. Jahwe is nie die God van dinge en plekke nie, maar van mense. Hy is nie 'n plekgod, 'n stadsgod, of 'n landgod nie. Hy is nie verbind aan plekke en dinge nie, maar aan mense; en wel in 'n verbondsverhouding. Hy is nie net 'n God van die koning (of die profeet nie), maar van die hele volk, soos blyk uit die belangrike plek wat die volk Israel in Dawid se gebed inneem (v. 23-26).

Wat Jahwe wil hê, is 'n persoonlike verhouding met Hom. Hy wil egter nie 'n indiwidualistiese verhouding he nie, maar, soos reeds aangedui, 'n verbondsverhouding, 'n verhouding waarin die mens ook in verbande met ander mense staan. Daar is byvoorbeeld, soos reeds hierbo aangedui is, die verhouding met die voorvaders en met die nageslagte, met die verlede en met die toekoms. Verder wys Jahwe vir Dawid op sy optrede in die geskiedenis: toe Hy Israel uit Egipte bevry het, en op die feit dat hulle sy volk is (v. 6-7). Dit is tipiese verbondsterme wat gebruik word wanneer Jahwe praat van "my volk (Israel)" (2 Sam. 7:7,8,10,11), en Dawid van "u volk (Israel)" (7:23-24), en van "hulle God" (letterlik "vir hulle 'n God geword") (7:24; Smith, 1969:303, teken by hierdie vers aan: "the well-known covenant relation").

Samevatting: Jahwe se korrektief op Dawid se voorgenome tempelbou wys dus die wese van die diens van Jahwe aan as persoonlik: Hy wil onder mense en in mense woon, nie in 'n lewelose gebou nie; by die hele volk, nie slegs by die koning (of profeet) nie; Hy vra die mens se hart, nie sy gawes nie; Hy vra persoonlike omgang met Hom in die hele spektrum van die lewe, nie bloot deelname aan die kultus of besoeke aan die erediens nie. Hy moet nie met mitologiese plekke geassosieer word nie, maar met sy optrede in die geskiedenis in belang van sy volk. Hy staan in ' $n$ 
verbondsverhouding met hulle. Jahwe wil 'n vader-kindverhouding hê; en soos by 'n gewone vader-kind-verhouding impliseer dit dat daar ook tug en kastyding moet wees vanweë kinderlike ontrou. Hiermee word die noodsaaklikheid van korrektiewe optrede deur Jahwe onderstreep. Dit geld nie alleen vir wanneer daar reeds verbrou is nie, maar ook ter voorkoming of ter waarskuwing. Jahwe se optrede is 'n korrektief op die menslike neiging om die ware aard van erediens en tempel te verontpersoonlik.

\section{VERBONDSTROU, VERKIESING EN BEKERING}

Hierdie gedeelte, sowel Jahwe se belofte aan Dawid as Dawid se reaksie daarop, benadruk die trou van Jahwe teenoor Dawid en sy nageslag (v.12-16; 18-29). Dié trou word aangesluit by en gemotiveer deur Jahwe se optrede in Dawid se lewe in die verlede, asook in die geskiedenis van die volk Israel sedert die uittog uit Egipte (v. 812). Jahwe sal sy trou (hesed) nie onttrek aan Dawid se seun aan wie Hy die besondere beloftes verbind nie. Hierdie Goddelike trou rus nie op menslike verdienste deurdat dié seun van Dawid sondeloos of onberispelik sal lewe nie. Inteendeel, die seun sal ontrou word, maar Jahwe sal hom straf soos 'n kind gestraf word. Daarvoor sal Jahwe mense as tugroede gebruik. Die seun sal as't ware op 'n indirekte manier deur die Here gestraf word, en nie deur sy direkte toorn wat vernietig nie. Hierdie milde optrede van Jahwe staan in skrille kontras met sy optrede teenoor Saul, en dit word ook deur Jahwe nadruklik daarteenoor gestel: "Maar my trou sal Ek nie aan hom onttrek soos Ek dit aan Saul onttrek het om vir jou plek te maak nie" (v.15). Dit gaan hier dus om Jahwe se verkiesing in die lewe van Dawid en van sy seun. Hierdie verkiesing impliseer nie sondeloosheid by dié wat uitverkies is nie, ook nie dat alles net vir hulle voorspoedig sal verloop nie. Dit impliseer wel kastyding en bekering, korrektiewe Vaderlike optrede en ootmoedige kinderlike reaksie. Verkiesing gaan om 'n lewe van God met sy gelowige volk, 'n lewe in gehoorsaamheid aan sy wil.

In hierdie hoofstuk (2 Sam. 7) kom iets na vore waarvan die lofsang van Hanna praat: "Jahwe verneder, ook gee Hy aansien" (1 Sam. 2:7). Hy beskerm sy troue dienaars op hulle pad, maar die goddeloses word stil gemaak in die duisternis van die graf. 'n Mens oorwin nie deur eie krag nie. Dié wat teen Jahwe in opstand kom, word vernietig ... . Hy verleen krag aan sy koning, Hy gee sterkte aan sy gesalfde" (v.9,10).

Jahwe se optrede, soos dit veral geopenbaar word in die geskiedenis van die koningskap by sy volk, is antiteties van aard. Hy bou aan sy volk wat Hom moet dien, maar hierdie bouwerk word gedurig deur persone en dinge bedreig en beveg, en hulle word deur Hom afgebreek en vernietig. Saul is 'n voorbeeld van so 'n persoon. Hy staan in hierdie hoedanigheid gedurig in die agtergrond van die geskiedenis van Dawid - Saul self sowel as sy nageslag (vgl. Kalsbeek, 1974:36 e.v.). 
Teenoor hierdie persone en dinge is Jahwe se weg een van antitese, vyandskap en vernietiging. Teenoor die ander, soos Dawid en sy seun in wie die ware volk van Jahwe verteenwoordig is, is Jahwe se weg 'n korrektiewe weg: dit is bouwerk deur loutering. Hierdie weg impliseer vir die volk van Jahwe antitese met die ander persone of groepe wat in werklikheid in vyandskap teenoor Jahwe staan; dit impliseer egter geen selfgenoegsaamheid nie. Daar is alleen plek vir ootmoed, want God se optrede berus nie op menslike verdienste nie, maar op Goddelike genade, verkiesing en trou, en word bewerkstellig langs die weg van 'n Goddelike korrektief in die lewe van sy gelowiges.

Die feit van die menslike onvermoë om aan die eis van God te voldoen enersyds, en God se korrektiewe optrede andersyds, is so beheersend dat dit aanleiding gee tot 'n belofte met sterk Messiaanse elemente, elemente wat slaan op 'n toekomstige Verlosserfiguur wat ver bokant die gewoon menslike uitgaan (vgl. Vriezen 1966:478), net soos in 1 Samuel 2:1-10 en 2 Samuel 22-23: "Jou koningshuis en jou koningskap sal vir altyd vas staan; jou troon sal altyd voortbestaan" (v.16; vgl. verder Dawid se gebed, veral v. 29; en verder die bespreking in punt 4.)

Samevattend kan ons stel: In teenstelling tot Jahwe se vernietigende optrede tecnoor Saul wat weens sy ontrou plek moes maak vir Dawid, is Jahwe se optrede teenoor Dawid en sy nageslag en sy volk beheers deur sy verkiesende genade en verbondstrou genade en verbondstrou wat straf maar ook vergewe. Hy eis ootmoed en bekering, maar Hy transendeer ook die gewone gang van sake deur Messiaanse beloftes te gee.

\section{DIE VERIIOUDING: ONVERGELYKLIKE GOD EN DILNAAR VAN GOD}

Dawid verkeer diep onder die indruk van die feit dat Jahwe die enigste, groot en onvergelyklike God is (v. 22). Daarteenoor beklemtoon Dawid soos met 'n refrein dat hy 'n dienaar van Jahwe is (v.20,21,25,26,27,27,28,29,29). Die term sowel as die beskrywing gee uitdrukking aan ootmoed, diensbaarheid en intimiteit en word ook in dieselfde betekenis gebruik vir persone soos die aartsvaders (Gen. 24:14; 26:24), Moses, Job en die profete (Num. 12:7-8; Job 1:8, 2:3, 42:7; Jer. 7:25).

Die woordcebed dui volgens Westermann (1976: 191-192) nie primêr onderworpenheid aan nie, maar 'n behoort aan die Here en geborgenheid by Hom. Om dienaar van Jahwe te wees, beteken altyd om 'n goeie Heer te hè. Verder, in onderskeid met die profete, konings en die aartsvaders, word 'n priester nie cebed genoem nie. Die kultiese optrede van die priester word onderskei van die historiese werk van God deur middel van die genoemde cabädim. Die veelvuldige gebruik van cebed in Dawid se gebed is dus in ooreenstemming met God se nadruk in ons Skrifgedeelte dat Hy nie in die eerste plek kulties gedien wil word nie maar in alle aspekte van die lewe. 
Die herhaalde gebruik van hierdie term, asook die wyse waarop dit deur Dawid gebruik word, onderstreep die punt waarom dit in Jahwe se weiering van Dawid se voorgenome tempelbou gaan: Jahwe is 'n persoonlike God en dit gaan vir Hom om 'n persoonlike verhouding met mense, sy gelowiges. Hy is nie 'n onpersoonlike, statiese God nie. Dié wat Hom vereer, moet dit nie onpersoonlik doen nie. Hulle is ook nie blote instrumente nie, maar dienaars van Jahwe - in 'n lewende verhouding met Hom en in persoonlike toegeneentheid, toewyding en verantwoordelikheid teenoor Hom.

Die aankondiging aan Dawid bereik sy klimaks in Jahwe se verhouding van trou met hom en sy nageslag (v.14-16). Dit is ook die geval met Dawid se gebed (v. 25-28). Dawid en sy nageslag is hier verteenwoordigers van Jahwe se volk Israel. Die doel van Jahwe se optrede is die ware verbondsverhouding met sy verbondsvolk. So word $\mathrm{Hy}$ geëer vir sy almag en sy trou: "En nou, Jahwe God, bevestig tog vir altyd wat U oor u dienaar en sy nageslag gesê het. Doen tog soos $\mathrm{U}$ belowe het, sodat $u$ Nam vir altyd groot kan wees as daar gesê word: "Die Here die Almagtige, is God van Israel"(v. $25,26)$.

Dit gaan vir Jahwe dus om hierdie verhouding. Tempel, stad, land en ander plekke of instellinge is aan hierdie verhouding diensbaar. Hulle mag nie verselfstandig word en 'n plek naas hierdie verhouding gegee word nie. Daar het wel steeds ' $n$ neiging daartoe bestaan. Daarvan was Saul ' $n$ voorbeeld; hy het gedink hy kan Jahwe met offerandes tevrede stel in plaas van met gehoorsaamheid. Maar laasgenoemde is beter as offerande, sê Samuel (1 Sam. 15:22). Daarom moet daar steeds na God se korrektiewe Woord gevra word.

Jahwe het dit nie teen 'n tempel, stad, land of ander plek vir sy volk as sodanig nic, aangesien hulle aan die ware verhouding tussen God en sy volk diensbaar kan wees. Brueggemann (1977:4), wat groot nadruk lê op die betekenis van land in die Ou Testament, maak dan ook tereg die volgende opmerking: "This sense of place is a primary concern of this God who refused a house and sojourned with his people (2 Sam. 7:56)." Tempelbou as sodanig word nie in hierdie hoofstuk veroordeel nie, en vers 13 is nie teenstrydig met Jahwe se weiering dat Dawid 'n tempel mag bou nie. Dawid se seun sal wel 'n tempel bou. Vir Dawid word dit geweier om sodoende die Goddelike korrektief vir alle verdere geslagte onvergeetlik voor oë te stel en vir alle eeue 'n appèl te maak op die regte gesindheid. God wat oor die hele lewe regeer, moet met 'n lewe van kinderlike gehoorsaamheid gedien word en nie met blote diens in 'n gebou nie. Hierdie gesindheid word bereik deur selfondersoek en bekering tot kinderlike gehoorsaamheid.

2 Samuel 7 staan dus ook nie teenoor Israel se danklied ná die deurtog deur die Rietsee in Eksodus 15 nie. Dáár trek die gebeurtenis van die uittog uit Egipte en die 
intog in die beloofde land daarin saam dat Jahwe vir Hom 'n gewyde plek gereed gemaak het (Eks. 15:17; vgl. Strauss, 1985:107; Fensham, 1970:85). Die feit dat die plek waarvandaan Jahwe regeer, daar beklemtoon word, moet gesien word binne die raamwerk van die gebeurtenisse waarom dit daar gaan: die uittog uit een plek (Egipte) waar Israel nie vir Jahwe kon dien soos dit moes nie, na 'n ander plek toe (die beloofde land), waar Israel Jahwe wel as hulle God en as Regeerder oor alles kan dien. Ook in Eksodus 15 gaan dit om die feit dat God vir ewig regeer (Eks. 15:18; 2 Sam. 7:26); ook daar gaan dit om die besondere verhouding tussen Jahwe en die volk wat Hy as sy eie volk, sy verbondsvolk, gemaak het (Eks. 15:16; 2 Sam. 7:23,24,26,27).

Samevattend: Dit gaan vir Jahwe om sy verhouding van trou met sy volk en dat dié wat Hom dien, dit doen as dienaars: in ootmoed, intimiteit en in toewyding van die hele lewe. Tempel, stad, land of ander plekke of instellinge moet hieraan diensbaar wees en mag nie 'n selfstandige plek naas hierdie verhouding inneem nie. Jahwe se weiering van Dawid se voorgenome tempelbou is bedoel as ' $n$ waarskuwing teen laasgenoemde gesindheid en is nie ' $n$ negatiewe beoordeling van ' $n$ tempel as sodanig nie.

\section{SAMEVATIING}

Die rede vir Jahwe se weiering van Dawid se voorgenome tempelbou is volgens 2 Samuel 7 nie dat die beweeglike nomadiese situasie van vroeër as ideaal gestel word teenoor die meer gevestigde nuwe situasie nie. Die weiering beklemtoon dat dit in Israel nie behoort te gaan om 'n menslike koninkryk, een waarin 'n menslike koning (en profeet) se mening die hoogste gesag is nie. Die inisiatief lê by Jahwe se Woord en optrede; Hy is die eintlike Regeerder, en die koning is sy dienaar. Die menslike koninkryk, met sy menslike insig, beplanning en optrede is skeef, al is dit die van die koning (en profeet) en vereis daarom 'n Goddelike korrektief.

Meer inhoudelik bekyk, beklemtoon die weiering van die tempelbou dat Jahwe nie 'n God is wat tot ' $n$ gebou of 'n kultus beperk is nie. Hy regeer oor die geskiedenis van sy volk en die nasies, en oor die lewe van elke gelowige. Daarom wil Hy nie bloot deur pligpleginge in die erediens gedien word nie, maar deur die mens se hele lewe, ' $n$ lewe van kinderlike omgang met Hom en gehoorsaamheid aan Hom. Hierin het volk en koning, saam met die profete in die algemeen, volgens die sogenaamde Deuteronomistiese geskiedenis misluk, en daarom het dit uitgeloop op die verlies van tempel en land (vgl. byvoorbeeld 2 Kon. 22:13;23:27; 24:13,15). 2 Samuel 7 verkondig dieselfde oor die wese van die ware godsdiens as die profete by monde van Miga 6:6,8: "Wat sal ek saamvat as ek na die Here toe gaan ...? Moet ek met offers na Hom toe gaan? Mens, die Here het aan jou bekend gemaak wat goed is: Hy vra dat jy reg sal laat geskied, dat jy liefde en trou sal bewys, dat jy bedagsaam sal lewe voor jou God." Dit gaan in 
die ware godsdiens om 'n verbondsverhouding waarin Hy geroem word as die Almagtige, die God van sy verbondsvolk (2 Sam 7:26).

2 Samuel 7 verkondig dus dat die diens van Jahwe, godsdiens, ten volle persoonlik is, die vrug van Goddelike verkiesing en verbondstrou en van sy korrektiewe Woord waardeur Hy gedurig tot bekering oproep en dit ook bewerkstellig. Jahwe is die Almagtige God. Menslike onvermoë sal Hom nie stuit om sy vaderlike trou te laat seëvier nie. Inteendeel, Hy maak vir sy volk 'n toekoms oop deur verwagtings wat bokant die oor 'n gewoon menslike koninkryk uitgaan - Messiaanse verwagtings. Hy sorg soos 'n vader vir sy kinders sorg, tugtigend en korrektief, en Hy vereis korrektiewe optrede, naamlik 'n lewe van bekering. Dit is ook die kenmerk van die sogenaamde Deuteronomistiese geskiedenis (Josua, Rigters, Samuel, Konings), 'n geskiedenis beheers deur God se straf en genade, van oproep tot bekering.

Hierdie korrektiewe aard van God se optrede en sy eis, en tegelykertyd die persoonlike aard daarvan, word veral duidelik verkondig in die oproep van Johannes die Doper: "Bekeer julle, want die koninkryk van God (die hemele) het naby gekom!" (Matt. 3:2).

\section{BIBLIOGRAFIE}

ACKROYD, P.R. 1981. The succession narrativc (so-called). Interpretation 35(4):383-3\%.

BOTHA, P.J. 1986. 2 Samucl 7 against the background of ancient near-eastern memorial inscriptions. (In Van Wyk, W.C.ed. Studies in the succession narrative. OTWSA 27 (1984) and OTWSA 28 (1985) Pretoria : UP. p.62-78)

BRUEggemanN, W. 1977. The land. Place as gift, promise and challenge in Biblical faith. London : SPCK

CAIRD, G.B. 1953. The first and second books of Samucl. New York: Abingdon Press. (The Interpreter's Bible.)

CHILDS, B.S. 1979. Introduction to the Old Testament as Scripturc. London : SCM.

CLEMENTS, R.E. 1965. God and temple. The idea of the divine presence in ancient Isracl. Oxford: Blackwcll.

DA VIES, W.D. 1974. The gospel and the land. Los Angeles : University of California Press.

DE VAUX, R. 1968. Ancient Isracl. Its life and institutions. London : Darton, Longman \& Todd.

FENSHAM, F.C. 1970. Exodus. Nijkcrk : Callcnbach. (De Prediking van het Oude Testament.)

GAMBERONI, 1984. Vs mäqsin. ThWAT. Stuttgart: Kohlhammer.

GOSLINGA, C.J. 1962. Het Tweede Boek Samucl. Kampen: Kok. (Commentaar op het Oude Testament.)

HERTZBERG, H.W. 1968. Die Samuelbücher, Goltingen : Vandenhocck \& Ruprecht. (Das Alte Testamcnt Deutsch. 10)

JENNI, E. 1976. vs Släm. ThWAT. Stuttgart : Kohlhammer.

KAISER, O. 1988. Bcobachtungen zur sogenannten Thronnachfolge-Erzählung Davids. Ephemerides Theologicae Lovanienses, 64:5-20, April.

KALSBEEK, G. 1974. De kompositic van de Samuëlboeken. Kerk en Theologie, 25(1): 31-54.

KEIL, C.F. 1950. The books of Samucl. Grand Rapids : Eerdmans. (Keil and Delitzsch Commentarics on the Old Testament.) 
KOEHLER-BAUMGARTNER, 1953. Lexicon in Veteris Testamenti Libros. Leiden : Brill.

MAAG, V. 1959. Malkût Yahweh. Leiden : Brill. (Sup. VT VII).

MARCH, W.E. 1981. II Samucl 7:1-17. Interpretation, 35(4):397-401.

ROST, L.R. 1\%65. Die Nathanswcissagung II Sam 7. (In Rost, L.R. red. Das Klcine Credo und andere Studien zum Alten Testament. Heidelberg : Qucllc \& Meyer. p. 159-183.)

SMITH, H.P.S. 1969. Samucl. (ICC.). Edinburgh : T. \& T. Clark.

STRAUSS, H. 1985. Das Mecrlied des Mose - cin 'Siegeslied' Isracls? (Bemerkungen zur theologischen Excgese von Ex 15,1-19. 20r.). ZAW, 97:103-109.

VAN DER WOUDE, A.S. 1976. vs säbä'. THAT. München : Kaiscr.

VAN ROOY, H.F. 1986. Nathan's promise and the succession history. (In Studics in the succession narrative. OTWSA 27 (1984) and OTWSA 28 (1985). Pretoria : UP. p. 321-338.)

VAN SELMS, A, 1967. Gencsis deel Il. Nijkerk : Callenbach (De Prediking van het Oude Testament).

VAN SETERS, J. 1983. In search of history: Historiography in the ancicnt world and the origins of Biblical history. New Haven : Yaic University Press.

VRIEZEN, TH.C. 1962. Jahwe en zijn stad. Amstcrdam : Koninklijke Nederlandsc Academic voor Wetenschappen.

VRIEZEN, TH.C. 1966. Hoofdijnen der theolngie van het Oude Testament. Wageningen : Veenman.

ZIMMERLI, W. 1971. Man and his hope in the Old Testament. London: SCM.

WESTERMANN, C. 1976. vs Cebed. THAT. München : Kaiser. 